\title{
Climatic effects on mosquito abundance in Mediterranean wetlands
}

\author{
David Roiz ${ }^{1,2}$, Santiago Ruiz ${ }^{3}$, Ramón Soriguer ${ }^{1}$ and Jordi Figuerola ${ }^{1 *}$
}

\begin{abstract}
Background: The impact of climate change on vector-borne diseases is highly controversial. One of the principal points of debate is whether or not climate influences mosquito abundance, a key factor in disease transmission.

Methods: To test this hypothesis, we analysed ten years of data (2003-2012) from biweekly surveys to assess inter-annual and seasonal relationships between the abundance of seven mosquito species known to be pathogen vectors (West Nile virus, Usutu virus, dirofilariasis and Plasmodium sp.) and several climatic variables in two wetlands in SW Spain.

Results: Within-season abundance patterns were related to climatic variables (i.e. temperature, rainfall, tide heights, relative humidity and photoperiod) that varied according to the mosquito species in question. Rainfall during winter months was positively related to Culex pipiens and Ochlerotatus detritus annual abundances. Annual maximum temperatures were non-linearly related to annual $C x$. pipiens abundance, while annual mean temperatures were positively related to annual Ochlerotatus caspius abundance. Finally, we modelled shifts in mosquito abundances using the A2 and B2 temperature and rainfall climate change scenarios for the period 2011-2100. While Oc. caspius, an important anthropophilic species, may increase in abundance, no changes are expected for $C$. pipiens or the salt-marsh mosquito Oc. detritus.

Conclusions: Our results highlight that the effects of climate are species-specific, place-specific and non-linear and that linear approaches will therefore overestimate the effect of climate change on mosquito abundances at high temperatures. Climate warming does not necessarily lead to an increase in mosquito abundance in natural Mediterranean wetlands and will affect, above all, species such as Oc. caspius whose numbers are not closely linked to rainfall and are influenced, rather, by local tidal patterns and temperatures. The final impact of changes in vector abundance on disease frequency will depend on the direct and indirect effects of climate and other parameters related to pathogen amplification and spillover on humans and other vertebrates.
\end{abstract}

Keywords: Mosquitoes, Climate change, Temperature, Rainfall, GAM, GLM, West Nile, Plasmodium, Dirofilariasis

\section{Background}

Vector-borne diseases (VBD) represent a serious threat to human health [1] and wildlife conservation [2]. Over the last three decades and concurrent to the emergence of newly recognized diseases, the incidence and geographic distribution of VBD have increased dramatically [3] and now account for almost one third of all cases of emerging diseases [4]. Although VBD transmission is determined by many factors, from host immunity to pathogen circulation, in recent years great emphasis has been placed on

\footnotetext{
* Correspondence: jordi@ebd.csic.es

'Wetland Ecology Department, Doñana Biological Station, CSIC, Sevilla, Spain Full list of author information is available at the end of the article
}

the notion that climate change may alter patterns of VBD transmission [5-10]. Climate influences various aspects of the vector-pathogen-host system and the existence of a close relationship between climate and the force of infection (i.e. the rate at which a population of hosts is infected) has been hypothesized [11]. Currently, our understanding of the underlying mechanisms that influence mosquito-borne disease transmission cycles is not complete and the potential impact of global warming on these diseases is today a subject of on-going debate and a source of controversy [7,12-15].

Climate has direct effects on vectors (e.g. abundance, distribution and longevity), pathogens (e.g. incubation 
period, replication and lineage), hosts (e.g. abundance, distribution and behaviour) and their interactions. Mosquito abundance is an important factor that conditions vectorial capacity and $R_{o}$ (the basic reproductive rate), and high abundance is often a prelude to an epidemic $[7,10]$. Previous studies have concluded that high temperatures and high rainfall are positively related to mosquito abundance; even so, in some cases mosquito abundance peaks are known to be preceded by periods of drought (Additional file 1).

West Nile virus (WNV), Chikungunya, Dengue and Usutu are considered to be (re)-emerging in Europe [9,16-18]. However, only limited information regarding the influence of climatic variables on the population dynamics of vectors in Europe is available [19-21]. In particular, WNV has become widespread [22-25] and disease outbreaks have occurred when epizootic vectors transmit this virus from birds to horses or humans [26]. Wetlands are linked to endemic WNV circulation [27] and here we study two wetlands in SW Spain where: 1) WNV circulation since at least 2003 has been documented regularly in resident birds [28,29], horses [30] and humans [31]; 2) there is a great abundance of several mosquito species potentially involved in disease transmission [32,33] (Table 1); and 3) outbreaks of WNV in humans and horses have been reported from a neighbouring province [34-36]. In addition, the mosquito-borne flavivirus Bagaza has been detected in the surrounding area [37], there is a high incidence of Dirofilaria immitis and the potential malarial vector Anopheles atroparvus is abundant (Table 1).

Consequently, we investigated the relationships between several climatic variables and the female abundance of seven mosquito species on inter-annual and seasonal scales in the period 2003-2012. We also modelled the potential effects of climate change on mosquito abundance using downscaled General Circulation Model outputs under two of the emission scenarios postulated by the Spanish National Meteorological Agency (AEMET).

\section{Methods}

\section{Study area}

The studied locations lie within the Doñana National Park and Odiel Natural Park in SW Spain (Figure 1). These two sites are included on the Ramsar list of wetlands of international importance and are classified as Biosphere reserves by UNESCO. The climate is Mediterranean subtropical in type, with hot dry summers and frequent rainfall in autumn and winter. The mean, maximum and minimum temperatures reported are $18.3,31.6$ and $7.7^{\circ} \mathrm{C}$, respectively, while mean annual rainfall is $516 \mathrm{~mm}$ (maximum monthly mean rainfall of $83 \mathrm{~mm}$ in December and minimum $1 \mathrm{~mm}$ in June). Doñana is a strongly seasonal freshwater wetland, while Odiel is very influenced by tides and has brackish wetlands. The most representative plants in the seasonal freshwater coastal areas are Scirpus maritimus L., S. littoralis Schrader, Typha latifolia L., and Phragmites australis (Cav.) Trin., while in tidal salt-marshes the vegetation is mainly composed of halophyte species such as Spartina densiflora Brongn, Salicornia ramossisima J. Woods, Sarcocornia perennis (Miller) A. J. Scott and Arthrocnemum macrostachyum (Moric.). In the Odiel salt-marshes operational mosquito control with the larvicide Bacillus thuringiensis var. israeliensis (Bti) (VectoBac 12 AS, Valent Biosciences, Libertyville, IL, USA) is carried out on a fortnightly basis every year from March to October. The avian communities of these wetlands are characterized by both migratory and sedentary species of ducks, herons, gulls, waders and other birds, with over 400 species and several millions of individuals recorded. Wild and domestic mammals (horses and cows) are also common, mainly in Doñana, and more than four million people visit the area annually, with a daily influx of more than 10,000 tourists during spring and summer.

\section{Mosquito sampling and data}

CDC (Centre for Disease Control) traps with 6-volt batteries were supplemented with a dry-ice tank of $1 \mathrm{~kg}$ capacity. Traps were located $2 \mathrm{~m}$ above ground level and were operated in 24-hour cycles. Trapping took place twice a week in February-November in 2003-2012. Traps were placed at three locations in areas of natural habitat for mosquitoes: Los Álamos (hereafter Álamos), Celestino Mutis (hereafter Mutis) and Palacio de Doñana (hereafter Palacio). Alamos and Mutis are near the tidal marshes of the Tinto and Odiel rivers, whilst Palacio is surrounded by the freshwater marshes of the Guadalquivir River (Figure 1). All three areas are environmentally protected and no landscape changes occurred in the area surrounding the traps during the study period. Mosquitoes were killed and transported to the laboratory on dry ice. Mosquitoes were counted, sexed and identified using taxonomic keys [38,39] with a stereomicroscope and a chill table.

\section{Environmental variables}

Temperature (mean, maximum, minimum), rainfall, relative humidity (mean, maximum and minimum), wind speed and direction, solar radiation, evapotranspiration and daylight hours during the study period were extracted from data from the closest meteorological stations to the trapping localities: Las Torres, Tomejil Moguer (http://www. mapa.es/siar/Informacion.asp) and Palacio de Doñana (http://www-rbd.ebd.csic.es/mediofisico/parametrosmeteor ologicos/palaciomanual/em05.htm). Tidal data were obtained from the Anuarios de Mareas del Instituto Hidrográfico de la Marina for the ports of Mazagón (Huelva) and Bonanza (Cadiz) at the mouth of the 
Table 1 Larval habitats and role in pathogen transmission of the main mosquito species detected in Doñana $[31,32,37,40-42,44,65]$

\begin{tabular}{|c|c|c|c|c|}
\hline Mosquito species & Larval habitats & $\begin{array}{l}\text { Vectorial competence } \\
\text { (laboratory) }\end{array}$ & $\begin{array}{l}\text { Field detection } \\
\text { in Doñana }\end{array}$ & Role as WNV vector \\
\hline \multirow[t]{4}{*}{ Culex pipiens } & Inundation areas & West Nile virus & West Nile virus & \multirow{4}{*}{$\begin{array}{l}\text { Enzootic and epizootic } \\
\text { West Nile vector }\end{array}$} \\
\hline & Rice fields & Rift Valley virus & & \\
\hline & Man-made water bodies. & & & \\
\hline & Nearly every kind of water source. & & & \\
\hline \multirow[t]{4}{*}{ Culex perexiguus (univittatus) } & Swamps & West Nile virus & West Nile virus & \multirow{4}{*}{$\begin{array}{l}\text { Enzootic and epizootic } \\
\text { West Nile vector }\end{array}$} \\
\hline & Ponds & & Usutu virus & \\
\hline & Ground pools & & & \\
\hline & Water wells. & & & \\
\hline \multirow[t]{5}{*}{ Culex modestus } & Irrigation channels & West Nile virus & & \multirow{9}{*}{$\begin{array}{l}\text { Enzootic West Nile } \\
\text { virus vector }\end{array}$} \\
\hline & Rice fields & Tahyna & & \\
\hline & Ground pools & Tularemia & & \\
\hline & Ponds & & & \\
\hline & Marshes. & & & \\
\hline \multirow[t]{4}{*}{ Culex theileri } & Marshes & $\begin{array}{l}\text { Dirofilaria immitis, West } \\
\text { Nile virus }\end{array}$ & & \\
\hline & Ditches & Rift Valley virus Sindbis & & \\
\hline & Swamps & & & \\
\hline & Rice fields & & & \\
\hline \multirow[t]{2}{*}{ Ochlerotatus caspius } & Halophilic species & West Nile virus & Mosquito Marsh virus & \\
\hline & Salt marshes, Tidal coastal marshes & Tahyna Tularaemia & & \\
\hline \multirow[t]{2}{*}{ Ochlerotatus detritus } & Halophilic species & & & \\
\hline & Salt marshes, Tidal coastal marshes & & & \\
\hline \multirow[t]{4}{*}{ Anopheles atroparvus } & Canals & Malaria & & \\
\hline & Ditches & & & \\
\hline & Marshes & & & \\
\hline & Rice fields & & & \\
\hline
\end{tabular}

Guadalquivir River. Data were pooled by week and the mean weekly values were computed for all variables except for rainfall, for which the total weekly precipitation was used (Figure 2).

\section{Statistical analysis of intra-annual (seasonal) patterns}

To control for temporal autocorrelation, we fitted an autoregressive time series model to the weekly female mosquito abundance data for each mosquito species, selecting the complexity with a model selection procedure based on Akaike's Information Criterion (AIC). With the order of the autoregressive time series, we fitted an ARIMA model to each female mosquito abundance time series. We extracted the residuals of the ARIMA that were used as the response variable for the intra-annual models. The explanatory variables were mean, maximum and minimum temperature, tide height, mean and total rainfall, wind speed, wind direction, solar radiation, evapotranspiration and photoperiod (daylight hours). Given that a time lag operates for the effects of climatic variables on larval abundance (and therefore on adult mosquito abundance), it is important to use aggregated climatic variables to detect biological relationships [40]. Therefore, a series of accumulated temperature, rainfall and tide variables were calculated for 1-4 weeks before the sampling week. The variables used in the analysis were the accumulated average temperature, accumulated rainfall and accumulated tide of $1-2,1-3,1-4,2-3,2-4$ and $3-4$ weeks before the sampling week. When the explanatory variables are highly correlated to each other, backward selection can select suboptimal models due to collinearity [41]. To select a set of unrelated independent variables, we compared the Variance Inflation Factor (VIF) of covariates, then excluded the covariate with the highest VIFs, recalculated the correlation and repeated the process until all VIF values were lower than four [42]. Based on this exploratory analysis, we selected the following explanatory variables: mean temperature during the week of capture, 


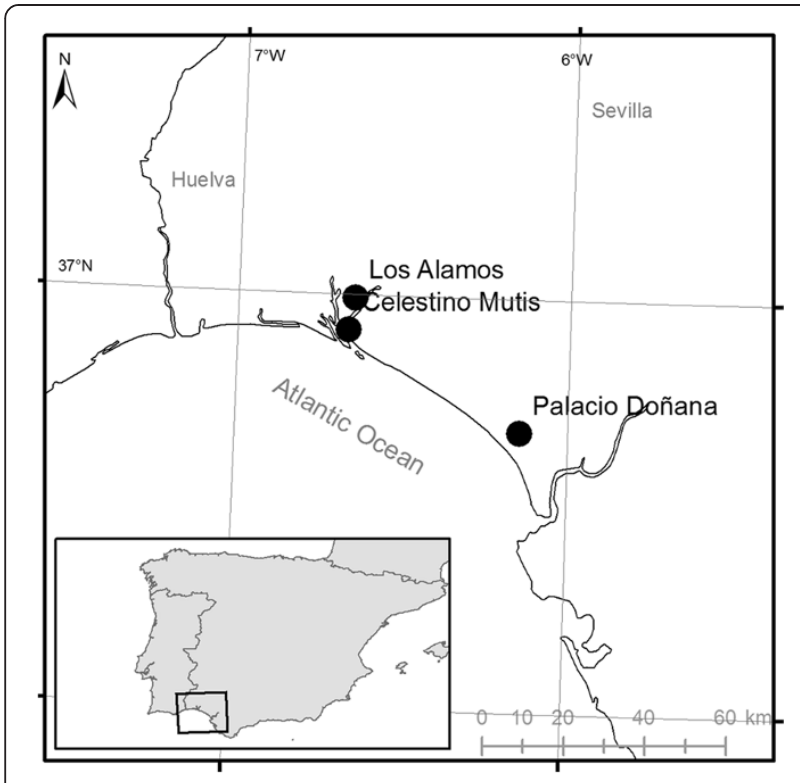

Figure 1 Map of the study area.

accumulated temperatures 1-4 weeks before capture, the accumulated tide heights two weeks before capture, accumulated tide heights 2-3 weeks before capture, mean relative humidity, wind speed, sum of rainfall during the week of capture, accumulated rainfall one week before capture, and accumulated rainfall 1-2 and 2-4 weeks before capture. Accumulated tide variables were only analysed in relation to the salt-marsh mosquitoes Ochlerotatus caspius and Oc. detritus, two species that use larval habitats that depend on tidal patterns. Given that the photoperiod is an important variable with a close collinearity to temperature, we performed a GLMM analysis for all species that only included photoperiod. For $C x$. theileri, $C x$. modestus and An. atroparvus we only used data from Palacio since in the two other localities these species were absent or only present in very low numbers. To model relationships between female mosquito abundance (residuals of the temporal autocorrelation model) and climatic covariates we performed a GLMM with Gaussian error. We fitted the models by pseudo-likelihood [43] and the minimal models were chosen using AICs for each variables and a forward stepwise model selection procedure [44]. All the independent variables were $\log 10$ transformed. Statistical analyses were performed using the R statistical package version 2.13.1 (2011 The R Foundation for Statistical computing).

\section{Statistical analysis of inter-annual patterns}

The effects of environmental variables on the estimates of annual average female mosquito abundances (2003-2012) in the commonest captured species were analyzed using Generalized Additive Models (GAMs). Given that the count data presented a significant overdispersion, the model was fitted using a negative binomial distributed error and a logarithm link [45]. The average number of
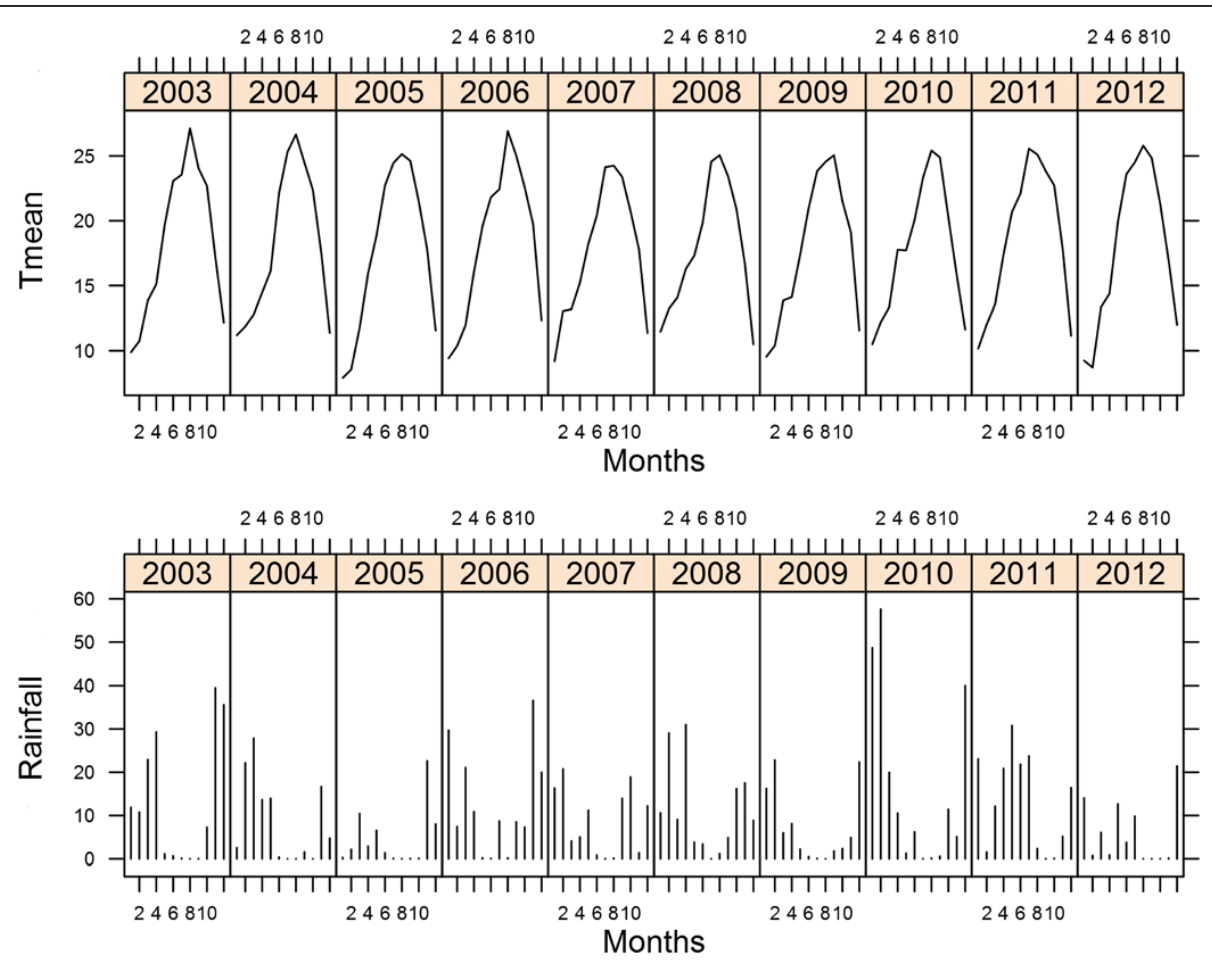

Figure 2 Seasonal dynamics of temperature and rainfall in the period 2003-2012. 
female mosquitoes was used as the response variable for each of the seven commonest species. The explanatory variables were as follows: average annual maximum temperature, annual mean temperature, average annual minimum temperature, annual rainfall and winter rainfall. Winter rainfall was calculated as the accumulated rainfall between September (week 40) and March of the following year (week 10). These variables were modelled including 'locality' as an independent factor and assuming that mean values for abundance may differ spatially. Model selection was performed using AICs for each variable and using a forward stepwise model selection procedure [44]; validation was performed based on Zuur [46]. The interannual analysis was only performed for $C x$. pipiens, Oc. caspius and $O c$. detritus because these mosquito species were the only ones regularly captured in all three localities. Statistical analyses were performed with the R statistical package version 2.13.1 (2011 The R Foundation for Statistical computing) using packages mgcv, lattice and MuMin, among others.

\section{Climate change scenarios}

The Spanish National Meteorological Agency (AEMET) has developed climate projections for the whole of the twenty-first century (http://www.aemet.es/es/elclima/cambio_climat/escenarios). We decided to use the Analogue INM' method used by the AEMET given that this statistical downscaling method, which presents the estimated data for temperature and rainfall in area E009 (Doñana) in the high-resolution reference grid for peninsular Spain and the Balearic Islands, provides the finest spatial resolution. This method provided us with the expected temperature (minimum and maximum) and rainfall values for the Doñana area using two General Circulation Models (GCMs), ECHAM (Max Planck Institute for Meteorology, Germany) and CGCM (Canadian Centre for Climate Modelling and Analysis), under the A2 and B2 emission scenarios. Scenario A2 is more extreme, and assumes self-reliance, the preservation of local identities, moderate economic development and a high growth in the global population; although energy consumption is high and changes in land use are moderately high, resources become scarce and technological change is fragmented but slower than under other scenarios. On the other hand, scenario B2 is more moderate than A2 and emphasizes environmental preservation and social equity with local solutions for economic, social and environmental sustainability; the global population is expected to increase continuously, yet more slowly than under scenario A2. B2 allows for a moderate level of economic development (like A2), but with lower energy consumption and fewer changes in land use; resources are more abundant and technological change is more diverse than under A2.
Based on the inter-annual models, we projected interannual variation in modelled female mosquito abundance based on the AEMET modelling and calculated the percentage shift in projected female mosquito abundance in the period 2011-2100 in relation to the reference period 1961-1990. Analyses were carried out using R software.

\section{Results}

\section{Mosquito sampling}

In total, 184 326 female mosquitoes belonging to seven species were captured (Table 2): Anopheles atroparvus Van Thiel, Culex pipiens Linnaeus, Culex theileri Theobald, Culex modestus Ficalbi, Culex perexiguus Theobald, Ochlerotatus caspius (Pallas) and Ochlerotatus detritus (Haliday). Oc. caspius was the most abundant species throughout the whole season, despite displaying a certain seasonality in its cycles (Figure 3). Cx. pipiens and Oc. detritus were abundant in all three localities in spring-summer and spring-autumn, respectively. Cx. theileri, $C x$. modestus, $C x$. perexiguus and $A n$. atroparvus were especially abundant at Palacio (Table 2 and Figure 4).

\section{Intra-annual relationships of climate and female mosquito} abundance

Mean temperature was positively related to $C x$. pipiens and Oc. caspius abundances (Table 3). Accumulated temperatures in the period 1-4 weeks (one month) before capture were positively related to $C x$. perexiguus and $C x$. modestus, and negatively to $C x$. pipiens and $O c$. detritus abundances. Accumulated rainfall during the period 2-4 weeks before capture was positively related to Oc. detritus abundance. Accumulated tide heights for two weeks before capture were positively related to Oc. caspius abundance and accumulated tide heights during 2-3 weeks before capture to Oc. detritus abundance. Mean relative humidity was negatively related to $C x$. theileri and An. atroparvus abundances (Table 3). None of the other variables were significant (Additional file 2). The photoperiod (hours of light) was positively related to $C x$. perexiguus, $C x$. theileri, An. atroparvus and Oc. caspius abundances but was negatively related to Oc. detritus abundance (Table 4).

\section{Interannual relationship of climatic variables and female mosquito abundance}

$C x$. pipiens abundance was positively related to annual maximum temperatures and winter rainfall. Annual mean temperatures were positively related to Oc. caspius (Table 5; Figure 5), while Oc. detritus abundance was positively related to winter rainfall.

\section{Climate change scenarios}

Using the increase in temperatures and decrease in rainfall in the study area forecasted by the scenarios (Figure 6), we projected variations in the abundances of female $C x$. 
Table 2 Number of female mosquitoes captured for the seven more abundant species collected between 2003-2012 in the three studied localities

\begin{tabular}{lcccccccc}
\hline Locality & $\begin{array}{c}\text { Oc. caspius } \\
\text { (\%) }\end{array}$ & $\begin{array}{c}\text { Oc. detritus } \\
(\%)\end{array}$ & $\begin{array}{c}\text { Cx. pipiens } \\
(\%)\end{array}$ & $\begin{array}{c}\text { Cx. theileri } \\
(\%)\end{array}$ & $\begin{array}{c}\text { Cx. modestus } \\
(\%)\end{array}$ & $\begin{array}{c}\text { Cx.perexiguus } \\
(\%)\end{array}$ & $\begin{array}{c}\text { An.atroparvus } \\
(\%)\end{array}$ & $\begin{array}{c}\text { Total mosquitoes } \\
\text { (\%) }\end{array}$ \\
\hline Álamos & $47015(81.46)$ & $1093(1.89)$ & $9159(15.84)$ & $324(0.56)$ & $105(0.18)$ & $18(0.03)$ & $1(0.01)$ & 57715 \\
Mutis & $13468(60.32)$ & $1100(4.93)$ & $7065(31.64)$ & $414(1.85)$ & $170(0.76)$ & $98(0.44)$ & $11(0.05)$ & 22326 \\
Palacio & $42902(41.14)$ & $544(0.52)$ & $1592(1.53)$ & $56680(54.35)$ & $1883(1.81)$ & $319(0.31)$ & $365(0.35)$ & 104285 \\
Total & $103385(56.09)$ & $2737(1.48)$ & $17816(9.67)$ & $57418(31.15)$ & $2158(1.17)$ & $435(0.24)$ & $377(0.2)$ & 184326 \\
\hline
\end{tabular}

pipiens, Oc. caspius and Oc. detritus. The other mosquito species were not represented because their interannual analysis did not give any significant variable. Under climate change scenarios A2 and B2 for the period 2013-2100, it is predicted that Oc. caspius abundance will considerably increase but that Oc. detritus and $C x$. pipiens abundances will not change (Figure 7). Although projections do not change qualitatively between scenarios, larger quantitative changes in mosquito populations are expected under the A2 scenarios.
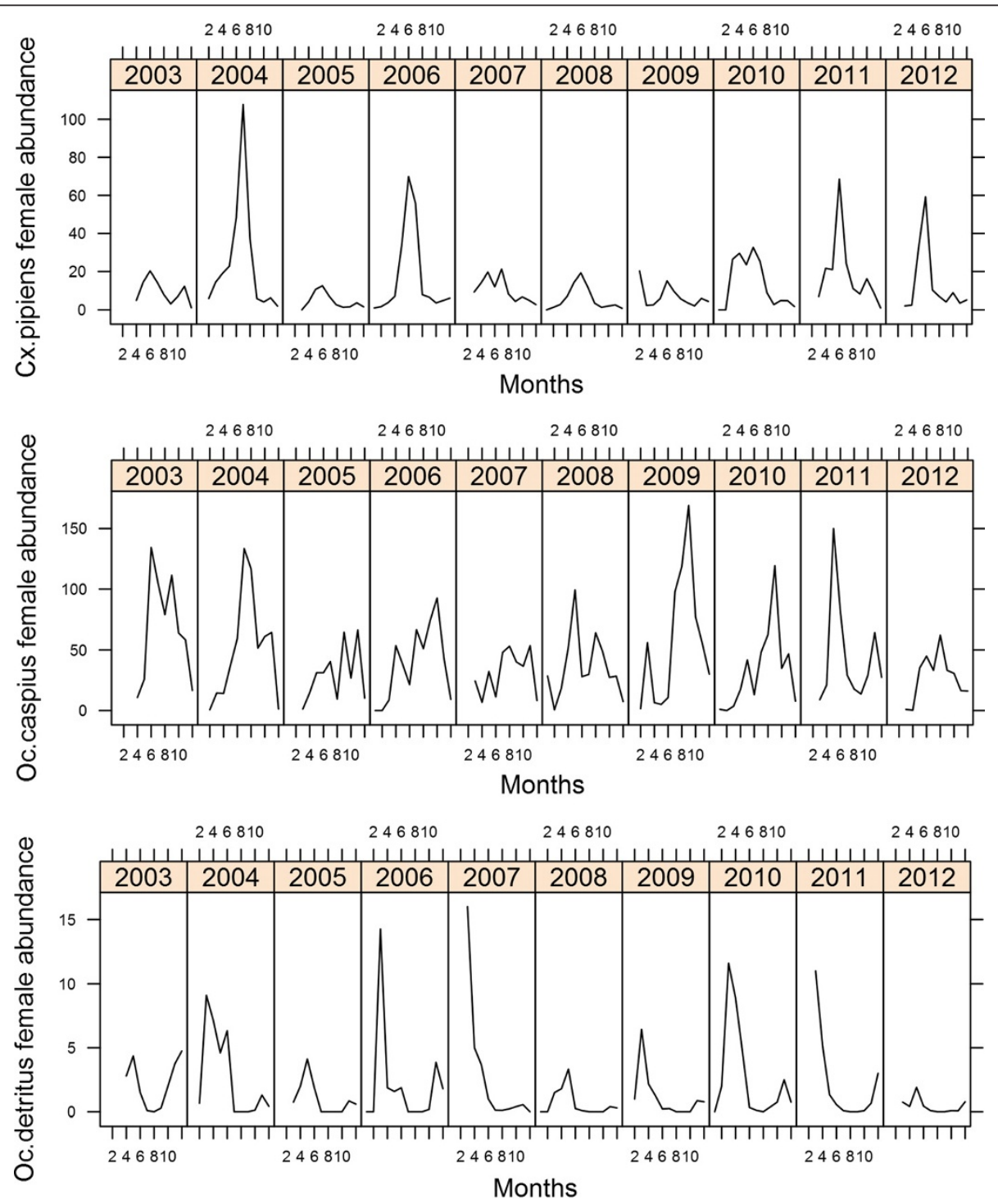

Figure 3 Seasonal dynamics of the three commonest mosquito species for all localities in the period 2003-2012. 

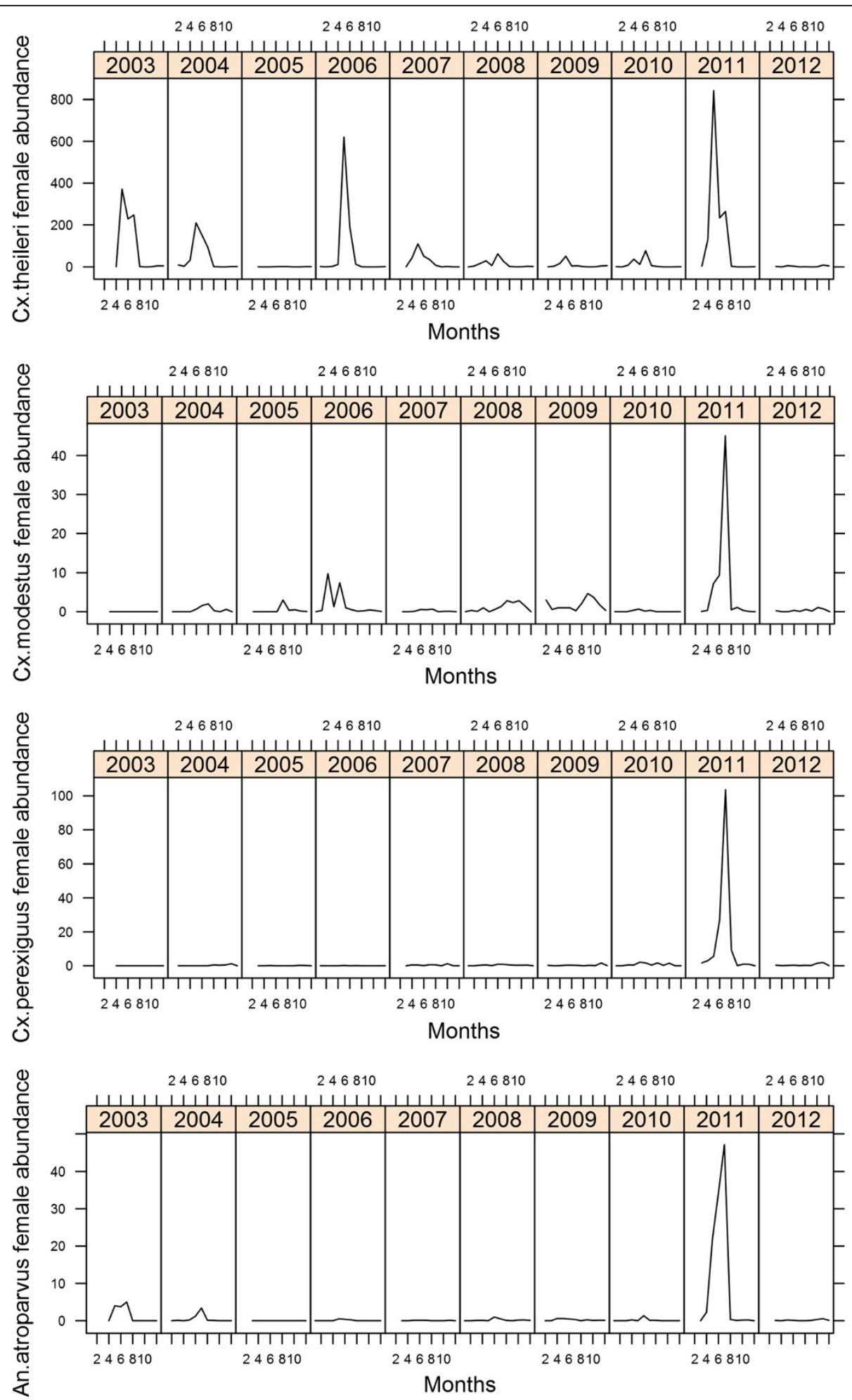

Figure 4 Seasonal dynamics of the four mosquito species present only at Palacio during the period 2003-2012.

\section{Discussion}

Mosquito abundance is related to climatic variables, although, depending on the species in question and the temporal scale used, the key variables will vary. Temperatures in general were positively related to mosquito abundance and can affect survival rates, mortality, larval 
Table 3 Results of the models (GLMM gaussian) for the significant climatic variables related to the seasonal patterns (intra-annual) of female abundance for seven species of mosquitoes

\begin{tabular}{|c|c|c|c|c|c|}
\hline Dependent variable & Independent variables & Coefficient $( \pm$ S.E) & t-value & df & p-value \\
\hline \multirow[t]{3}{*}{ Culex pipiens } & Intercept & $5.5012 \pm 3.6666$ & & & \\
\hline & Mean temperature & $0.9404 \pm 0.3449$ & 2.726 & 1,787 & 0.0065 \\
\hline & Accumulated temperature 1-4 weeks & $-0.3240 \pm 0.0910$ & -3.560 & 1,787 & 0.0004 \\
\hline \multirow[t]{2}{*}{ Culex perexiguus } & Intercept & $-1.4462 \pm 0.4680$ & & & \\
\hline & Accumulated temperature 1-4 weeks & $0.0213 \pm 0.0061$ & 3.473 & 1,214 & 0.0006 \\
\hline \multirow[t]{2}{*}{ Culex modestus } & Intercept & $-3.7820 \pm 1.2065$ & & & \\
\hline & Accumulated temperature 1-4 weeks & $0.0624 \pm 0.0158$ & 3.946 & 1,214 & 0.0001 \\
\hline \multirow[t]{2}{*}{ Culex theileri } & Intercept & $90.7469 \pm 44.2425$ & & & \\
\hline & Mean relative humidiy & $-1.3653 \pm 0.6473$ & -2.109 & 1,214 & 0.0361 \\
\hline \multirow[t]{2}{*}{ Anopheles atroparvus } & Intercept & $2.1637 \pm 0.6365$ & & & \\
\hline & Mean relative humidity & $-0.0337 \pm 0.0093$ & -3.623 & 1,214 & 0.0003 \\
\hline \multirow[t]{3}{*}{ Ochlerotatus caspius } & Intercept & $-306.1215 \pm 75.4695$ & & & \\
\hline & Accumulated tide 2 weeks before & $6.34085 \pm 1.8209$ & 3.482 & 1,787 & 0.0005 \\
\hline & Mean temperature & $1.9980 \pm 0.6247$ & 3.198 & 1,787 & 0.0014 \\
\hline \multirow[t]{4}{*}{ Ochlerotatus detritus } & Intercept & $-9.2316 \pm 2.4513$ & & & \\
\hline & Accumulated tide 2-3 weeks before & $0.2489 \pm 0.0586$ & 4.241 & 1,786 & $<0.0001$ \\
\hline & Accumulated temperature 1-4 weeks & $-0.0260 \pm 0.0111$ & -2.343 & 1,786 & 0.0194 \\
\hline & Accumulated rainfall 2 to 4 weeks & $0.02949 \pm 3.3909$ & 0.006 & 1,786 & $<0.0001$ \\
\hline
\end{tabular}

productivity and other population parameters $[7,10]$. Weekly temperatures were related to seasonal abundance patterns in Cx. pipiens and Oc. caspius, while accumulated temperatures (1-4 weeks before) were positively related to $C x$. modestus and $C x$. perexiguus abundances. These results are consistent with previous studies in USA, South Africa and Russia that link high summer temperatures to great vector abundance and WNV outbreaks [20,47-49].
On the other hand, accumulated temperatures (1-4 weeks before) were negatively related to $C x$. pipiens and $O c$. detritus abundances. These negative relationships, like the negative effect of annual maximum temperatures over $40^{\circ} \mathrm{C}$ on $\mathrm{Cx}$. pipiens abundance (Figure 5), may reflect the negative effect of high temperatures on mosquito longevity and life expectancy [50]. These two mosquito species may be more sensitive to high temperatures,

Table 4 Results of the models (GLMM gaussian) for the relationship between photoperiod (hours of light) and the seasonal patterns (intra-annual) of female abundance for seven species of mosquitoes

\begin{tabular}{|c|c|c|c|c|c|}
\hline Dependent variable & Independent variables & Coefficient $( \pm$ S.E) & $\mathbf{F}$ & df & p-value \\
\hline \multirow[t]{2}{*}{ Culex pipiens } & Intercept & $-10.48657 \pm 6.391346$ & & & \\
\hline & Photoperiod & $18.44723 \pm 10.870908$ & 1.697 & 1, 788 & 0.0901 \\
\hline \multirow[t]{2}{*}{ Culex modestus } & Intercept & $0.02061 \pm 2.44786$ & & & \\
\hline & Photoperiod & $1.52955 \pm 4.66071$ & 0.328 & 1,214 & 0.743 \\
\hline \multirow[t]{2}{*}{ Culex perexiguus } & Intercept & $-2.1168 \pm 0.9235$ & & & \\
\hline & Photoperiod & $4.2972 \pm 1.7547$ & 2.449 & 1,214 & 0.0151 \\
\hline \multirow[t]{2}{*}{ Culex theileri } & Intercept & $-173.79 \pm 52.79$ & & & \\
\hline & Photoperiod & $331.21 \pm 100.51$ & 3.295 & 1,214 & 0.00115 \\
\hline \multirow[t]{2}{*}{ Ochlerotatus caspius } & Intercept & $-85.99189 \pm 26.18172$ & & & \\
\hline & Photoperiod & $157.28911 \pm 45.26570$ & 3.475 & 1,788 & 0.0005 \\
\hline \multirow[t]{2}{*}{ Ochlerotatus detritus } & Intercept & $3.026271 \pm 1.499752$ & & & \\
\hline & Photoperiod & $-6.133728 \pm 2.703791$ & 2.269 & 1, 788 & 0.0236 \\
\hline \multirow[t]{2}{*}{ Anopheles atroparvus } & Intercept & $-2.3264 \pm 0.7793$ & & & \\
\hline & Photoperiod & $4.2522 \pm 1.4838$ & 2.866 & 1,214 & 0.00458 \\
\hline
\end{tabular}


Table 5 Results of the models (Generalized Additive Models) for the significant climatic variables related to inter-annual (between years) patterns of female abundance for three species of mosquitoes that were captured regularly in the three localities

\begin{tabular}{|c|c|c|c|c|c|}
\hline Dependent variable & Independent variables & df & Chi-sq & p-value & Deviance explained (\%) \\
\hline \multirow[t]{2}{*}{ Culex pipiens } & Annual maximum temperature & 2 & 7.694 & 0.02134 & 72.8 \\
\hline & Winter rainfall & 2 & 11.467 & 0.00324 & \\
\hline Ochlerotatus caspius & Annual mean temperatures & 1.73 & 11.61 & 0.00293 & 55.7 \\
\hline Ochlerotatus detritus & Winter rainfall & 1 & 6.656 & 0.00988 & 43.7 \\
\hline
\end{tabular}

although an indirect effect may also exist given that high evapotranspiration and the absence of larval habitats coincide with the period of highest temperatures.

Accumulated rainfall (2-4 weeks before) is positively related to Oc. detritus weekly abundance. We did not detect any relationship between drought periods and mosquito abundance as has been reported in other studies [51-53]. However, both $C x$. theileri and An. atroparvus within-year abundances are negatively related to relative humidity, which could be due to drought, to an effect on flight activity, or to high evapotranspiration. In general, the relationship rainfall-mosquito abundance is variable and depends on differences in the ecology and habitat selection patterns of each mosquito species.

The influence of tide heights on the abundance of saltmarsh species has previously been reported by [54]: both Oc. caspius and Oc. detritus weekly abundances were related to tide height, albeit with a time lag of 1-2 weeks before capture in the former and of 2-3 weeks in the latter. This lag corresponds to the fortnightly seasonal rhythms of these species, which benefit from the high tides that flood the saltmarshes and create larval breeding sites [38]. We did not detect any effect of wind on within-year abundance patterns. Wind may negatively affect captures by reducing flight activity of mosquitoes [55] and it is important to remember that the number of captures in mosquito traps depends not only on mosquito abundance but also on mosquito activity [56].

Photoperiod (day-length) was positively related to the within-year abundance patterns of $C x$. perexiguus, $C x$. theileri, Oc. caspius and An. atroparvus, but negatively to Oc. detritus. Day-length is an important variable in spring emergence and autumn decline, especially in species that enter into diapause, and probably affects the seasonal
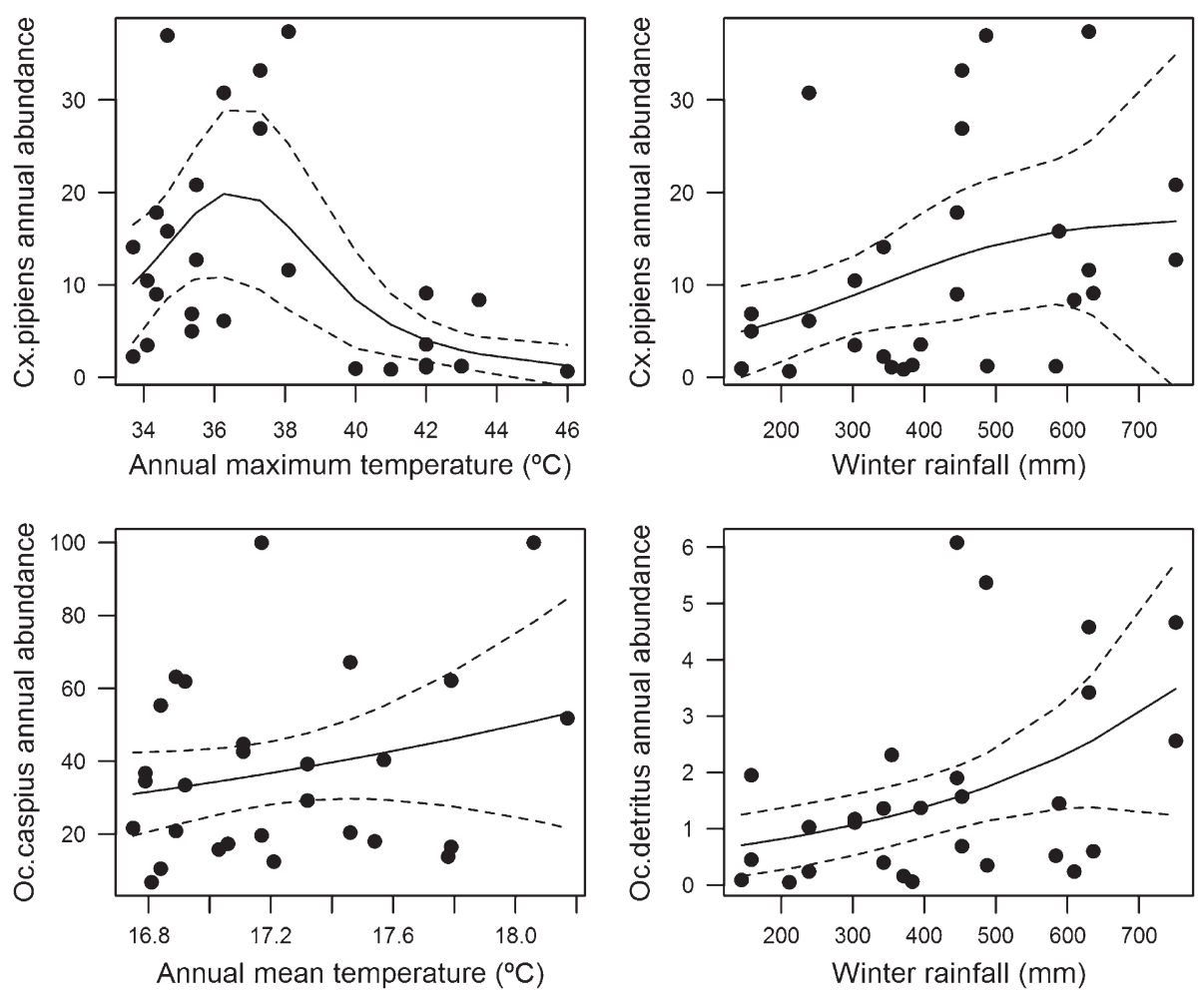

Figure 5 Relationship (GAMs) of climatic variables and interannual patterns of mosquito abundance. 


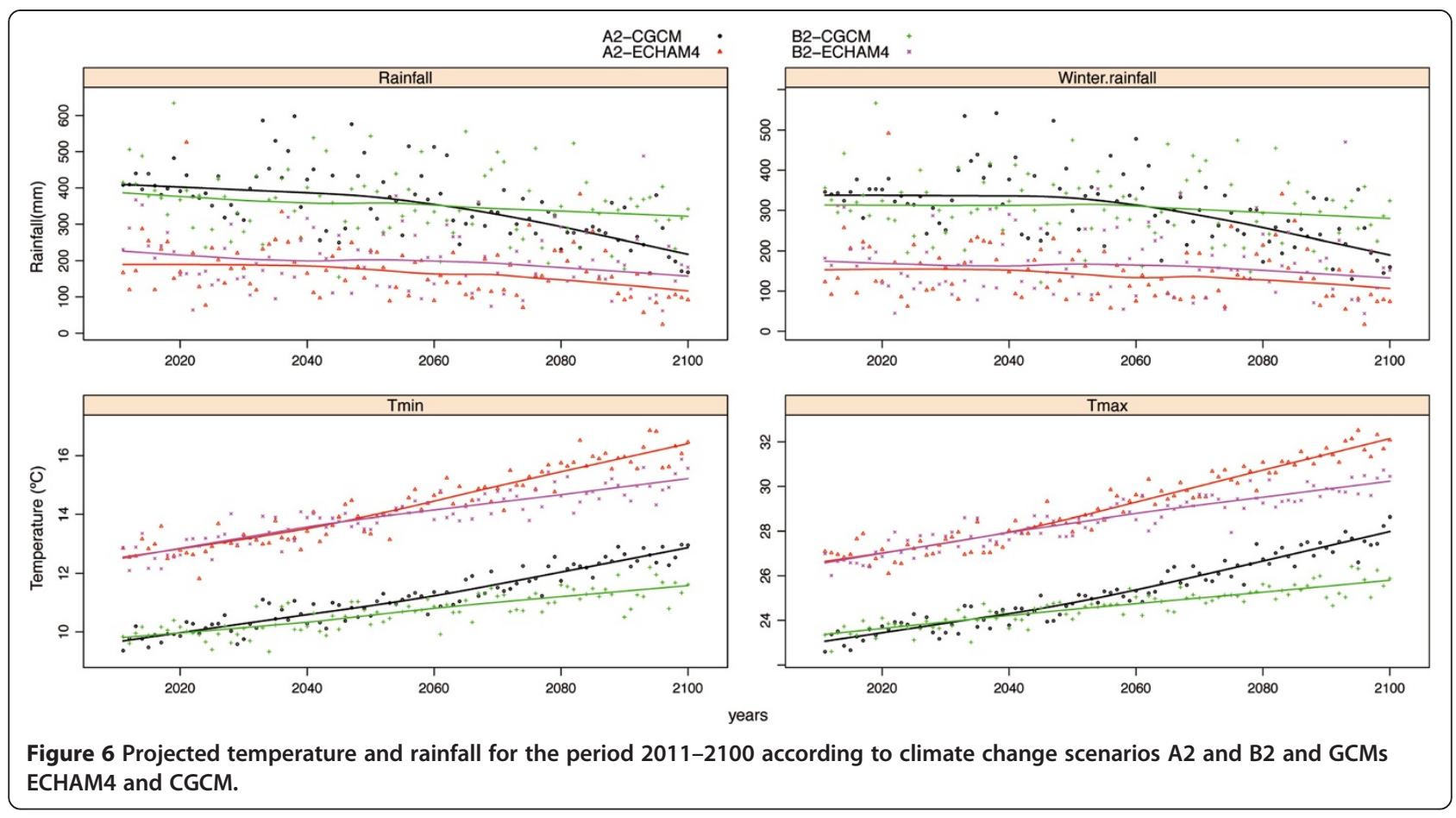

dynamics of mosquito abundance in several species. Unlike temperature or rainfall, the seasonal pattern in day-length does not vary from year to year and provides a highly reliable anticipatory cue for future seasonal conditions [57]. However, few studies have ever considered the photoperiod as an important variable affecting seasonal dynamics in mosquito populations [58]. Overall, our results agree with several previous studies (Additional file 1) that conclude that higher temperatures and greater accumulated temperatures, as well previous (winter) rainfall,

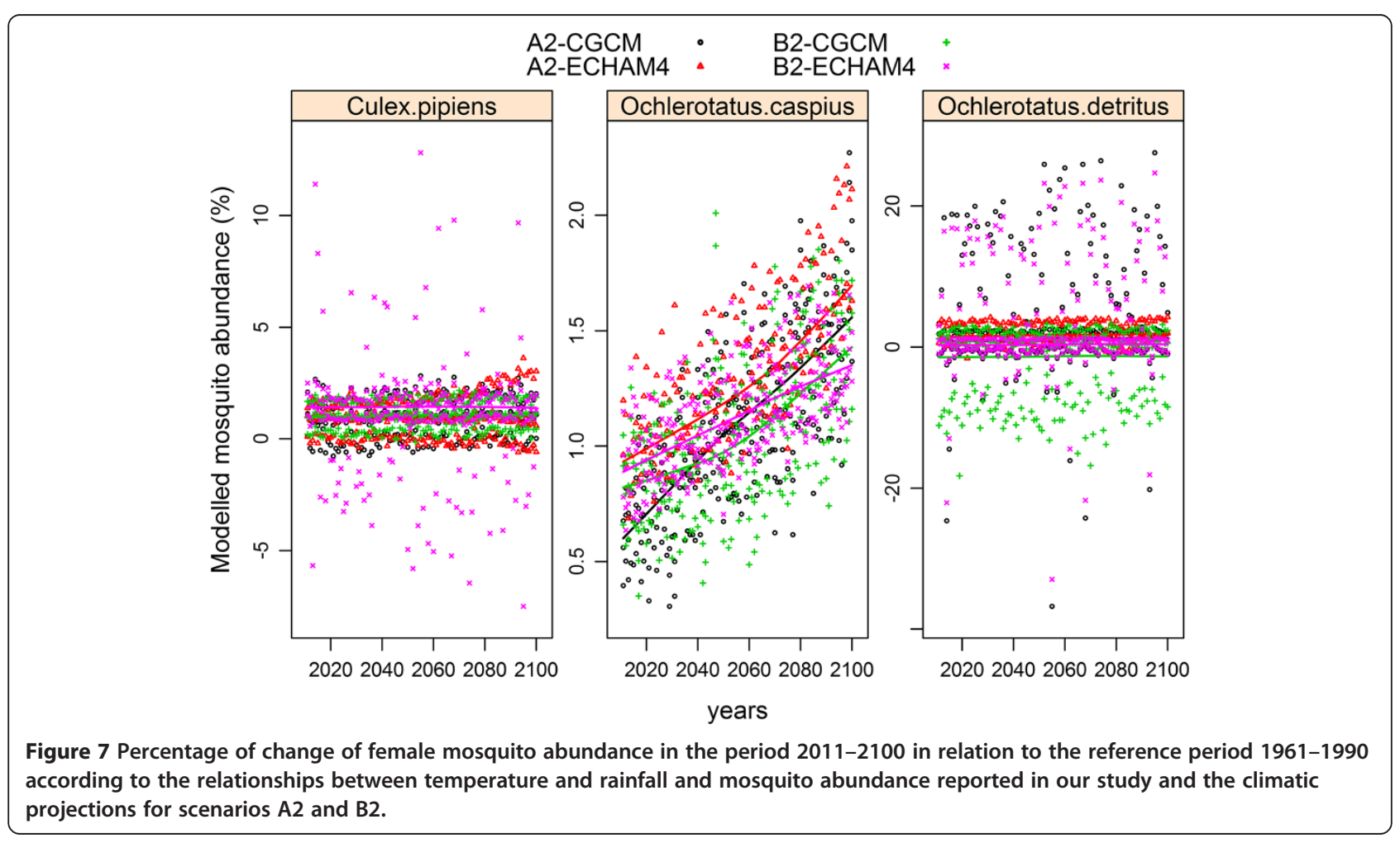


are all important factors that help explain mosquito abundance.

Annual temperatures were related non-linearly to the inter-annual patterns of mosquito abundance in $C x$. pipiens (maximum temperature) and Oc. caspius (mean temperatures). The influence of annual rainfall on mosquito abundance is a controversial question (Additional file 1); the results of our study show that previous rainfall is an important variable that is positively related to $C x$. pipiens and Oc. detritus annual abundances.

When analysing long-term series of mosquito abundance data it is important to consider the effects that changes in larvicide treatments may have had. In our case it is unlikely that our results were affected by changes in pesticide treatment given that no such treatment is used within $45 \mathrm{~km}$ of Palacio. At the other two sites, however, the tidal areas suitable for Oc. caspius and Oc. detritus larval development were treated with larvicides, but at a distance of over $1 \mathrm{~km}$ from the traps. The product and amount used did not change over time and treatment was applied in a fortnightly cycle after high tides. This periodicity would have hindered rather than favoured our ability to detect any relationship between tides and population size within seasons and probably had no effect on inter-annual analysis or climate change modelling. Additionally, no landscape changes that could have affected the mosquito populations were detected during the study period.

The Spanish National Meteorological Agency AEMET projections suggest that climate change will have particularly marked effects in southern Spain and will lead to higher temperatures and lower rainfall [59]. Given the projections under $\mathrm{A} 2$ and $\mathrm{B} 2$ climate change scenarios and assuming the existence of a causal relationship between the climatic variables we studied and female mosquito abundance, we do not expect that any important shift (increase or decrease) in either Cx. pipiens (a WNV and USUV vector) or the salt-marsh mosquito Oc. detritus abundances will occur. The already abundant and anthropophilic pest mosquito Oc. caspius, a potential vector of diseases such as Tahyna, WNV and tularemia [38], could greatly increase in abundance, especially under the A2 climate change scenario (Figure 7), that is, more extreme estimates of change than under B2. Oc. caspius has a great resistance to high temperatures and drought, is active, bites at high temperatures (up to $36^{\circ} \mathrm{C}$ in adults and $33^{\circ} \mathrm{C}$ in larvae), and tolerates high salinities due to its great capacity for osmotic regulation [60]. This species depends heavily on areas flooded with brackish water in estuaries during high tides in the Atlantic and, consequently, its populations are less rainfall dependent than other species. In Doñana, we have described its bloodmeal behaviour as mammalophilic, since more than $90 \%$ of its blood meals are derived from mammals, but it has little importance in the amplification of WNV in the area [32]. In addition, in recent years the novel flavivirus Marisma Mosquito Virus has been detected in Oc. caspius pools analysed in the area [61], although the potential pathogenicity (if any) of this virus for vertebrates has yet to be demonstrated. We expect that the nuisance caused by Oc. caspius to local populations will increase in the future, although its implications for disease dynamics are unclear. Oc. detritus and Oc. caspius depend on tide patterns that vary in terms of sea levels and so, hypothetically, rising sea levels under global warming could lead to an increase in salt-marsh mosquito abundance [62]. Projections of seasonal changes in rainfall patterns suggest a decrease in spring and summer precipitations and an increase in the length of drought periods [63]. Consequently, we would also expect changes in the phenology of mosquito abundance. The reliability of these projections depends on the nature of the relationship between climate and mosquito abundance, which will have to be confirmed with manipulative experiments in addition to the observational evidence presented here since the relationship between climate and life-history processes are not likely to be linear [71]. The next challenge is to accurately understand the contribution of multiple interacting and often non-linear underlying responses in hosts, pathogens and vectors to climate [64].

\section{Conclusions}

When we reviewed the studies analysing correlations between climatic variables and WNV human cases and infection rates, the same variables (temperature and rainfall) were related to vector mosquito abundance, infection rates and cases of infection in humans (Additional file 1). Moreover, mosquito abundance has been directly related to the basic reproductive rate $R_{o}$ (the total number of secondary cases arising from one infective case in a susceptible population) and the vectorial capacity $\mathrm{C}$ (the daily rate at which secondary cases arise from a currently infective case) $[7,10]$. Additionally, temperature alters the replication of the virus in the mosquito - the extrinsic incubation period (EID) - and therefore infection rates $[48,65]$. In this work, we focus on how climate change could influence transmission by altering mosquito vector abundance. An important question, given that models for vector-borne diseases use the number of vectors per host, is whether the number of vectors caught in a trap is related to the number of vectors per host [66]. Come what may, the effects of temperature are complex due to the fact that the climate-mosquito abundance relationship is species-specific and time-dependent, and long data series are needed to continue the study of these trends in mosquito abundance. Our results highlight the fact that these effects are non-linear (see Figure 5, Cx. pipiens and maximum temperatures) and that, therefore, linear 
approaches will overestimate the effect of climate change on mosquito abundances at high temperatures. Without additional studies our results are not generalizable to other habitats since relationships may vary between areas and may be place-specific $[49,51]$. Although it is likely that anthropogenic changes in modified wetlands will be more determinant than climate [67], this study was conducted in natural wetlands unaffected by any serious anthropogenic change such as population increase or agricultural and urban expansion. Thus, our results show that climate change does not necessarily lead to an increase in mosquito populations. Simplistic and generalist statements assuming that higher temperatures lead to more mosquitoes are not adequate and it is essential to carry out a careful analysis of temporal patterns in field data. In addition, climate is likely to affect other important parameters for disease transmission (such as vector survival and pathogen development rates) and, consequently, it is not possible to extrapolate from conclusions regarding climate and mosquito abundances to the risk of disease outbreaks. Other non-climatic variables (i.e. socio-economic development, circulation of pathogenic strains, pathogen replication, host ecology, anthropogenic changes, land use/land-cover and inundation patterns) may also be determinant when analysing the risk of vector-borne disease emergence [68]. Greater understanding of the ecology of vector-borne disease is essential if we are to understand the effects of global change on vector-borne disease outbreaks, an important challenge for future decades.

\section{Additional files}

Additional file 1: Review of several studies of the effect of climatic variables on WNV cases, mosquito infection rate and vector abundance.

Additional file 2: Results of the models (GLMM gaussian) for all the climatic variables that are related with seasonal patterns (intra-annual) of female abundance for seven mosquito species and the estimates of the final model selected by backward selection. Significant variables are in bold. The significance $(F, p)$ of the non-significant variables corresponds to the final model plus the non-significant variable.

\section{Competing interests}

The authors declare that they have no competing interests.

\section{Authors' contributions}

SR designed and participated in field sampling; DR, SR and JF organised the analyses, results and discussion; DR analysed the data; JF and RS provided financial support. All the authors were involved in the drafting of the manuscript and gave their approval to the final version.

\section{Acknowledgments}

We would like to thank Juani Moreno and Antonio Magallanes from the Mosquito Control Service, Huelva, Spain, as well as Esmeralda Perez Morueta, Isidro Román and Pilar Bayon from the Estación Biológica de Doñana, Seville, Spain, for their help and technical support. This work was partially supported by projects P07-RNM-02511, RNM118 and RNM157 of the Junta de Andalucía, Plan Nacional of the Spanish Ministry of Science (CGL2009-11445), and the European Commission EDEN FP6, EuroWestnile EU grant HEALTH.2010.2.3.3-3 Project 261391 and EDENext FP7 project.

\section{Author details}

${ }^{1}$ Wetland Ecology Department, Doñana Biological Station, CSIC, Sevilla, Spain. 2Present address: UMR 224 MIVEGEC/BEES, IRD, Montpellier, France. ${ }^{3}$ Diputación de Huelva, Área de Medio Ambiente, Servicio de Control de Mosquitos, Huelva, Spain.

Received: 22 March 2014 Accepted: 26 June 2014

Published: 16 July 2014

\section{References}

1. Gratz NG: Emerging and resurging vector-borne diseases. Annu Rev Entomol 1999, 44:51-75.

2. Daszak P, Cunningham AA, Hyatt AD: Anthropogenic environmental change and the emergence of infectious diseases in wildlife. Acta Trop 2001, 78(2):103-116.

3. Gubler DJ: The Global Threat of Emergent/Re-emergent Vector-Borne Diseases. In Vector Biology, Ecology and Control. Edited by Atkinson PW. Dordrecht: Springer Netherlands; 2010:39-62.

4. Taylor LH, Latham SM, Woolhouse MEJ: Risk factors for human disease emergence. Philos T Roy Soc B 2001, 356(1411):983-989.

5. Shope R: Global climate change and infectious diseases. Environ Health Persp 1991, 96:171-174.

6. Epstein PR: Global warming and vector-borne disease. Lancet 1998, 351(9117):1737.

7. Reiter P: Climate change and mosquito-borne disease. Environ Health Persp 2001, 109(Suppl 1):141-161.

8. Patz JA, Campbell-Lendrum D, Holloway T, Foley JA: Impact of regional climate change on human health. Nature 2005, 438(7066):310-317.

9. Gould EA, Higgs S: Impact of climate change and other factors on emerging arbovirus diseases. Trans Roy Soc Trop Med Hyg 2009, 103(2):109-121.

10. Lafferty KD: The ecology of climate change and infectious diseases. Ecology 2009, 90:888-900.

11. Dobson A: Climate variability, global change, immunity, and the dynamics of infectious diseases. Ecology 2009, 90:920-927.

12. Brisbois BW, Ali SH: Climate change, vector-borne disease and interdisciplinary research: social science perspectives on an environment and health controversy. EcoHealth 2010, 7(4):425-438.

13. Rogers DJ, Randolph SE, Simon I, Hay AG, David JR: Climate Change and Vector-Borne Diseases. In Global Mapping of Infectious Diseases: Methods, Examples and Emerging Applications. London: Academic Press; 2006:345-381.

14. Rohr JR, Dobson AP, Johnson PTJ, Kilpatrick AM, Paull SH, Raffel TR, Ruiz-Moreno D, Thomas MB: Frontiers in climate change-disease research. Trends Ecol Evol 2011, 26(6):270-277.

15. Patz JA, Graczyk TK, Geller N, Vittor AY: Effects of environmental change on emerging parasitic diseases. Int J Parasitol 2000, 30(12-13):1395-1405.

16. Rezza G, Nicoletti L, Angelini R, Romi R, Finarelli AC, Panning M, Cordioli P, Fortuna C, Boros S, Magurano F: Infection with chikungunya virus in Italy: an outbreak in a temperate region. Lancet 2007, 370(9602):1840-1846.

17. Vazquez A, Jimenez-Clavero M, Franco L, Donoso-Mantke O, Sambri V, Niedrig M, Zeller $\mathrm{H}$, Tenorio A: Usutu virus: potential risk of human disease in Europe. Eurosurveillance 2011, 16(31):19935.

18. Lindgren E, Andersson Y, Suk JE, Sudre B, Semenza JC: Monitoring EU emerging infectious disease risk due to climate change. Science 2012, 336(6080):418-419.

19. Savage HM, Ceianu C, Nicolescu G, Karabatsos N, Lanciotti R, Vladimirescu A, Laiv L, Ungureanu A, Romanca C, Tsai TF: Entomologic and avian investigations of an epidemic of West Nile fever in Romania in 1996, with serologic and molecular characterization of a virus isolate from mosquitoes. Am J Trop Med Hyg 1999, 61(4):600-611.

20. Platonov AE, Shipulin GA, Shipulina OY, Tyutyunnik EN, Frolochkina TI, Lanciotti RS, Yazyshina S, Platonova OV, Obukhov IL, Zhukov AN: Outbreak of West Nile virus infection, Volgograd Region, Russia, 1999. Emerg Infect Dis 2001, 7(1):128-132.

21. Ponçon N, Toty C, L'ambert G, Le Goff G, Brengues C, Schaffner F, Fontenille D: Population dynamics of pest mosquitoes and potential malaria and West Nile virus vectors in relation to climatic factors and human activities in the Camargue, France. Med Vet Entomol 2007, 21(4):350-357.

22. Hubálek $Z$, Halouzka J: West Nile fever-a reemerging mosquito-borne viral disease in Europe. Emerg Infect Dis 1999, 5(5):643-650. 
23. Calistri P, Monaco F, Savini G, Guercio A, Purpari G, Vicari D, Cascio S, Lelli R: Further spread of West Nile virus in Italy. Vet Ital 2010, 46(4):467-474.

24. Angelini $P$, Tamba M, Finarelli AC, Bellini R, Albieri A, Bonilauri P, Cavrini F, Dottori M, Gaibani P, Martini E: West Nile virus circulation in Emilia-Romagna, Italy: the integrated surveillance system 2009. Eurosurveilancel 2010, 15(16):19547.

25. Danis K, Papa A, Papanikolaou E, Dougas G, Terzaki I, Baka A, Vrioni G, Kapsimali V, Tsakris A, Kansouzidou A: Ongoing outbreak of West Nile virus infection in humans, Greece, July to August 2011. Eurosurveillance 2011, 16(34):19951.

26. Kramer LD, Styer LM, Ebel GD: A global perspective on the epidemiology of West Nile virus. Annu Rev Entomol 2008, 53(1):61-81.

27. Jourdain E, Gauthier-Clerc M, Bicout D, Sabatier P: Bird migration routes and risk for pathogen dispersion into Western Mediterranean Wetlands. Emerg Infect Dis 2007, 13(3):365-372

28. Figuerola J, Jimenez-Clavero MA, Rojo G, Gomez-Tejedor C, Soriguer R: Prevalence of West Nile virus neutralizing antibodies in colonial aquatic birds in southern Spain. Avian Pathol 2007, 36(3):209-212.

29. Figuerola J, Jimenez-Clavero MA, Lopez G, Rubio C, Soriguer R, Gomez-Tejedor C, Tenorio A: Size matters: West Nile virus neutralizing antibodies in resident and migratory birds in Spain. Vet Microbio/ 2008, 132(1-2):39-46.

30. Jimenez-Clavero MA, Llorente F, Sotelo E, Soriguer R, Gomez-Tejedor C, Figuerola J: West Nile virus serosurveillance in horses in Donana, Spain, 2005 to 2008. Vet Rec 2010, 167(10):379-380.

31. Bernabeu-Wittel M, Ruiz-Pérez M, del Toro MD, Aznar J, Muniain Á, de Ory F, Domingo C, Pachón J: West Nile virus past infections in the general population of Southern Spain. Enferm Infec Micr Cl 2007, 25(9):561.

32. Muñoz J, Ruiz S, Soriguer R, Alcaide M, Viana DS, Roiz D, Vázquez A Figuerola J: Feeding patterns of potential West Nile virus vectors in South-West Spain. PLOS ONE 2012, 7(6):e39549.

33. Vazquez A, Sanchez-Seco MP, Ruiz S, Molero F, Hernandez L, Moreno J, Magallanes A, Tejedor CG, Tenorio A: Putative new lineage of west nile virus, Spain. Emerg Infect Dis 2010, 16(3):549-552

34. Sotelo E, Fernández-Pinero J, Jiménez-Clavero MÁ: La fiebre/encefalitis por virus West Nile: reemergencia en Europa y situación en España. Enferm Infec Micr Cl 2012, 30(2):75-83.

35. García-Bocanegra I, Jaén-Téllez JA, Napp S, Arenas-Montes A, Fernández-Morente M, Fernández-Molera V, Arenas A: West Nile fever outbreak in horses and humans, Spain, 2010. Emerg Infect Dis 2011, 17(12):2397-2399.

36. Sotelo E, Gutierrez-Guzmán A, del Amo J, Llorente F, El-Harrak M, Pérez-Ramírez E, Blanco J, Höfle U, Jiménez-Clavero M: Pathogenicity of two recent Western Mediterranean West Nile virus isolates in a wild bird species indigenous to Southern Europe: the red-legged partridge. Vet Res 2011, 42:11.

37. Aguero M, Fernández-Pinero J, Buitrago D, Sánchez A, Elizalde M, San Miguel E, Villalba R, Llorente F, Jiménez-Clavero MA: Bagaza virus in partridges and pheasants, Spain, 2010. Emerg Infect Dis 2011, 17:1498-1501.

38. Becker N, Petric D, Zgomba M, Boase C, Madon M, Dahl C, Kaiser A: Mosquitoes and Their Control. Berlin: Springer; 2010.

39. Schaffner F, Angel G, Geoffroy B, Hervy JP, Rhaiem A, Brunhes J: Les moustiques d'Europe/The mosquitoes of Europe. CD-ROM Montpellier. France: Institut de Recherche pour le Développement/EID Méditerranée; 2001.

40. Shone SM, Ferrao PN, Lesser CR, Norris DE, Glass GE: Analysis of mosquito vector species abundances in Maryland using geographic information systems. Ann NY Acad Sci 2006, 951:364-368.

41. Zuur AF, leno EN, Smith GM: Analysing Ecological Data. Berlin: Springer; 2007.

42. Zuur AF, leno EN, Elphick CS: A protocol for data exploration to avoid common statistical problems. Methods Ecol Evol 2010, 1(1):3-14.

43. Bolker BM, Brooks ME, Clark CJ, Geange SW, Poulsen JR, Stevens MHH, White J: Generalized linear mixed models: a practical guide for ecology and evolution. Trends Ecol Evol 2009, 24(3):127-135.

44. Crawley MJ: Statistical Computing: an Introduction to Data Analysis using S-Plus. Chichester: John Wiley and Sons; 2002.

45. Ver Hoef JM, Boveng PL: Quassi-poisson vs. negative binomial regression: how should we model overdispersed count data? Ecology 2007, 88:2766-2772

46. Zuur AF: A Beginner's Guide to Generalized Additive Models with R. Newburg: Highland Statistics Ltd; 2014.

47. Jupp PG: The ecology of West Nile virus in South Africa and the occurrence of outbreaks in humans. Ann NY Acad Sci 2001, 951(1):143-152.
48. Reisen WK, Fang Y, Martinez VM: Effects of temperature on the transmission of west nile virus by Culex tarsalis (Diptera: Culicidae). J Med Entomo/ 2006 43(2):309-317

49. Ruiz MO, Chaves LF, Hamer GL, Sun T, Brown WM, Walker ED, Haramis L, Goldberg TL, Kitron UD: Local impact of temperature and precipitation on West Nile virus infection in Culex species mosquitoes in northeast Illinois, USA. Parasit Vectors 2010, 3(1):19.

50. Tabachnick WJ: Challenges in predicting climate and environmental effects on vector-borne disease episystems in a changing world. $J$ Exp Biol 2010, 213(6):946-954

51. Landesman WJ, Allan BF, Langerhans RB, Knight TM, Chase JM: Inter-annual associations between precipitation and human incidence of West Nile virus in the United States. Vector-Borne Zoonot 2007, 7:337-343.

52. Shaman J, Day JF, Stieglitz M: Drought-induced amplification and epidemic transmission of West Nile virus in Southern Florida. J Med Entomol 2005, 42:134-141.

53. Uejio CK, Kemp A, Comrie AC: Climatic controls on West Nile virus and Sindbis virus transmission and outbreaks in South Africa. Vector-Borne Zoonot 2011, 12(2):117-125.

54. Leisnham PT, Sandoval-Mohapatra S: Mosquitoes associated with ditch-plugged and control tidal salt marshes on the Delmarva Peninsula. Int J Environ Res Public Health 2011, 8(8):3099-3113.

55. Hribar $\amalg$, DeMay DJ, Lund UJ: The association between meteorological variables and the abundance of Aedes taeniorhynchus in the Florida Keys. J Vector Ecol 2010, 35(2):339-346.

56. Matowo NS, Moore J, Mapua S, Madumia EP, Moshi IR, Kaindoa EW, Mwangungulu SP, Kavishe DE, Sumaye RD, Lwetoijera DW, Okumu FO: Using a new odour-baited device to explore options for luring and killing outdoor-biting malaria vectors: a report on design and field evaluation of the Mosquito Landing Box. Parasites and Vectors 2013, 6:137.

57. Bradshaw WE, Holzapfel CM: Climate change. Evolutionary response to rapid climate change. Science 2006, 312(5779):1477-1478.

58. Gong H, DeGaetano A, Harrington L: Climate-based models for West Nile Culex mosquito vectors in the Northeastern US. Int J Biometeorol 2011, 55(3):435-446

59. Brunet M, Casado MJ, de Castro M, Galán P, López JA, Martín JM, Pastor A, Petisco E, Ramos P, Ribalaygua J: Generación de escenarios de cambio climático regionalizados para España. Madrid: Agencia Estatal de Meteorología, Ministerio de Medio Ambiente; 2009:158.

60. Bradley TJ: Physiology of osmoregulation in mosquitoes. Annu Rev Entomol 1987, 32:439-462.

61. Vázquez A, Sánchez-Seco M-P, Palacios G, Molero F, Reyes N, Ruiz S, Aranda C, Marqués E, Escosa R, Moreno J, Figuerola J, Tenorio A: Novel flaviviruses detected in different species of mosquitoes in Spain. Vector-Borne Zoonot 2012, 12(3):223-229.

62. Ramasamy R, Surendran SN: Global climate change and its potential impact on disease transmission by salinity-tolerant mosquito vectors in coastal zones. Front Physio/ 2012, 3:198.

63. de Castro M, Martín-Vide J, Alonso S: El clima de Espana: Pasado, Presente Y Escenarios de Clima para el Siglo XXI. In Evaluación Preliminar de los Impactos en España por Efecto del Cambio Climático. Edited by Moreno-Rodríguez JM. Madrid: Ministerio de Medio Ambiente; 2005:1-64.

64. Altizer S, Ostfeld RS, Johnson PTJ, Kutz S, Harvell CD: Climate change and infectious diseases: from evidence to a predictive framework. Science 2013, 341(6145):514-519.

65. Kilpatrick AM, Meola MA, Moudy RM, Kramer LD: Temperature, viral genetics, and the transmission of West Nile virus by Culex pipiens mosquitoes. PLoS Pathog 2008, 4(6):e1000092.

66. Baylis M: Research gaps in understanding how climate change will affect arboviral diseases. Anim Health Res Rev 2013, 14(02):143-146.

67. Ponçon N, Tran A, Toty C, Luty AJF, Fontenille D: A quantitative risk assessment approach for mosquito-borne diseases: malaria re-emergence in southern France. Malaria J 2008, 7(1):147.

68. Kilpatrick AM: Globalization, land use, and the invasion of West Nile virus. Science 2011, 334(6054):323-327.

\section{doi:10.1186/1756-3305-7-333}

Cite this article as: Roiz et al:: Climatic effects on mosquito abundance in Mediterranean wetlands. Parasites \& Vectors 2014 7:333. 